\title{
Populating Sub-entries in Dictionaries with Multi-word Units from Concordance Lines
}

\author{
Thapelo J. Otlogetswe, Department of English, University of Botswana, \\ Gaborone, Botswana (otlogets@mopipi.ub.bw)
}

\begin{abstract}
Lexicography is primarily concerned with the representation of words and their senses in dictionaries. By words most dictionary users and lexicographers refer to a combination of characters delineated by spaces on both sides. This article discusses the weakness of this approach in the selection of dictionary entries. Through an inspection of concordance lines generated from a multi-million Setswana corpus, it is argued and demonstrated how multi-word units (MWUs), also known as multi-word expressions (MWEs), may be extracted from concordance lines to supplement dictionary entries. It is illustrated how both monolingual and bilingual Setswana dictionaries may be enhanced by the addition of MWEs as sub-entries.
\end{abstract}

Keywords: SETSWANA, LEXICOGRAPHY, MULTI-WORD UNIT, CORPUS, CONCORDANCE, MULTI-WORD EXPRESSION, COLLOCATION, WORD, SUB-ENTRIES, DICTIONARY

Opsomming: Die aanvulling van subinskrywings in woordeboeke met meerwoordige eenhede uit konkordansiereëls. Leksikografie is hoofsaaklik gemoeid met die weergawe van woorde en hul betekenisse in woordeboeke. Met woorde verwys die meeste woordeboekgebruikers en leksikograwe na 'n kombinasie van lettertekens afgegrens deur spasies aan beide kante. Hierdie artikel bespreek die swakheid van hierdie benadering by die keuse van woordeboekinskrywings. Deur 'n ondersoek van konkordansiereëls gegenereer uit 'n multimiljoenSetswanakorpus, word daar geredeneer en verduidelik hoe meerwoordige eenhede (MWE's), ook bekend as meerwoordige uitdrukkings (MWU's), uit konkordansiereëls onttrek kan word om woordeboekinskrywings aan te vul. Daar word angetoon hoe sowel eentalige as meertalige Setswanawoordeboeke uitgebrei kan word deur die toevoeging van MWU's as subinskrywings.

Sleutelwoorde: SETSWANA, LEKSIKOGRAFIE, MEERWOORDIGE EENHEID, KORPUS, KONKORDANSIE, MEERWOORDIGE UITDRUKKING, KOLLOKASIE, WOORD, SUBINSKRYWINGS, WOORDEBOEK

\section{Introduction}

At the centre of lexicography lies the problem of what constitutes a word. The problem is not only a lexicographic one. It is also a linguistic one. McArthur (1998: 45-47) identifies eight types of words: orthographic, phonological, morphological, lexical, grammatical, onomastic, lexicographical and statistical words. 
What constitutes words is critical in corpus linguistics, since it translates into the problem of what gets counted by the computer. Lexicographically, those ones considered as words are listed in the dictionary.

\section{The word problem}

In frequency analysis, there is therefore a need to clarify what constitutes a word in a language and how words get counted. In linguistic literature, the term word is defined in a variety of ways. Some of these definitions, while useful for theoretical linguistics, are useless for computational word counts. Finch (2000: 132) defines a word as "a unit of expression which native speakers intuitively recognize in both spoken and written language" and adds that "there is a certain indeterminacy about the definition of a word". Finch's definition is unhelpful in that "a unit of expression" could be anything from a word, a phrase, a clause or a sentence. His definition also leaves the determination of what a word is to a speaker's intuition which may vary from one speaker to another. Aitchison (1992: 49) points out that "the best-known definition of a word is the one proposed by the American linguist Bloomfield who defined it as a minimum free form, that is, the smallest form that can occur by itself". She further argues that distinctions must be made between lexical items, syntactic words and phonological words. If we consider lexical items, a form such as fly represents at least two words:

\section{fly [noun]: an insect with two wings.}

fly [verb]: to move through the air in a controlled manner.

The two lexical items have different syntactic forms associated with them. The noun could either be singular (fly) or plural (flies). The verb on the other hand could occur as fly, flying, flies, flew and flown. This therefore raises problems for the Bloomfieldian approach.

Leech et al. (1982: 27) consider a word as "delimited, for most purposes by a space (or punctuation mark other than a hyphen or apostrophe) on each side". This is known in linguistic literature as an orthographic word. However they also acknowledge that "the boundaries of words ... are not always clear; e.g. we can write the sequence piggy + bank in three ways: piggy bank, piggybank, or piggybank".

In most computational processes, a word is treated as a "minimal free form, the smallest unit that can exist on its own" (Dash and Chaudhuri 2000: 189) and "delimited by a space ... on each side" (Leech et al. 1982: 27). This approach is helpful if one is studying forms delineated by spaces. However, in this article, larger units which have spaces within them are studied. Moon (1998) calls these fixed expressions and idioms. In other literature they are called multi-word units or MWUs (Schone and Jurafsky 2001) or multi-word expressions or MWEs (Sharroff 2004; Oflazer and Çetinoğlu 2004; Villavicencio 
et al. 2004; Fazly and Stevenson 2007). Bannard (2007: 1) gives the following definition:

A multi-word unit is usually taken to be any word combination (adjacent or otherwise) that has some feature (syntactic, semantic or purely statistical) that cannot be predicted on the basis of its component words and/or the combinatorial processes of the language. Such units need to be included in any language description that hopes to account for actual usage.

Sag et al. (2002: 2) characterize MWEs as "idiosyncratic interpretations that cross word boundaries (or spaces)". And if Jackendoff's (1997: 156) estimate that the number of MWEs in a speaker's lexicon is of the same order of magnitude as the number of single words, then MWEs deserve focus and will significantly enhance dictionary entries.

MWEs therefore include idioms, phrasal verbs, proverbs, compound words, etc. English examples are by and large, kick the bucket, in step, take up, take off, shake up, telephone booth, pull strings, fresh air, fish and chips, salt and pepper, etc. Setswana examples are solegela molemo (benefit), kukega maikutlo (be upset), iphaga dikoro (involve oneself in other people's business), tsholetsa maoto/dinaô (walk faster), opisa tlhogo (cause trouble), tsaya karolo (participate), tsaya tsia (pay attention), nna le seabe (take part), ja monate (enjoy), etc. The immediate problem arises with their identification, since they can be written in diverse and inconsistent ways. Take for example the following different spellings which are acceptable in both English and Setswana as written in Botswana.

$\begin{array}{lll}\begin{array}{l}\text { houseboat } \\ \text { tradeoff }\end{array} & \begin{array}{l}\text { house-boat } \\ \text { trade-off }\end{array} & \begin{array}{l}\text { house boat } \\ \text { trade off }\end{array} \\ \text { khuduthamaga } & \text { khudu-thamaga } & \text { khudu thamaga } \\ \text { pelotshetlha } & \text { pelo-tshetlha } & \text { pelo tshetlha } \\ \text { rampatshetlha } & \text { rampa-tshetlha } & \text { rampa tshetlha } \\ \text { motshwaradiphala } & \text { motshwara-diphala } & \text { motshwara diphala } \\ \text { kgakalakgakala } & \text { kgakala-kgakala } & \text { kgakala kgakala }\end{array}$

The examples houseboat and kgakalakgakala will each constitute a single token, while house boat and kgakala kgakala will form two tokens each. Words joined by a hyphen can either be recognized as single words or as two separate words depending on the tokenizing program. The difference is not trivial in statistical linguistics, since the number of tokens will vary significantly depending on what is counted.

\section{Methodology and experiments}

For our experiments, we follow Brunner and Steyner (2008) and use corpus data. By a corpus is meant, according to Renouf (1987: 1), "a collection of texts, 
of written or spoken words, which is stored and processed on computer for the purpose of linguistic research". The Setswana corpus used for the experiments is just over 13 million tokens. The software employed is Oxford Wordsmith Tools Version 4 (Scott 2004-2006). It is applied to study a specific word in context in some detail in terms of co-texts to its left and to its right. This is achieved by generating a key word in context (KWIC), often referred to as concordance lines. Dash and Chaudhuri (2000: 190) give the following definition:

A concordance is an index of the surface word forms in a text. It is a collection of the occurrences of a word form, each in its own textual environment.

A concordance reveals the context of a word, its collocates, and thereby reveals meanings and usages which are hard to recover through mental recall (Otlogetswe 2007: 56). We illustrate this below with the example of the word pelo (heart).

Figure 1: Concordance results for the word pelo

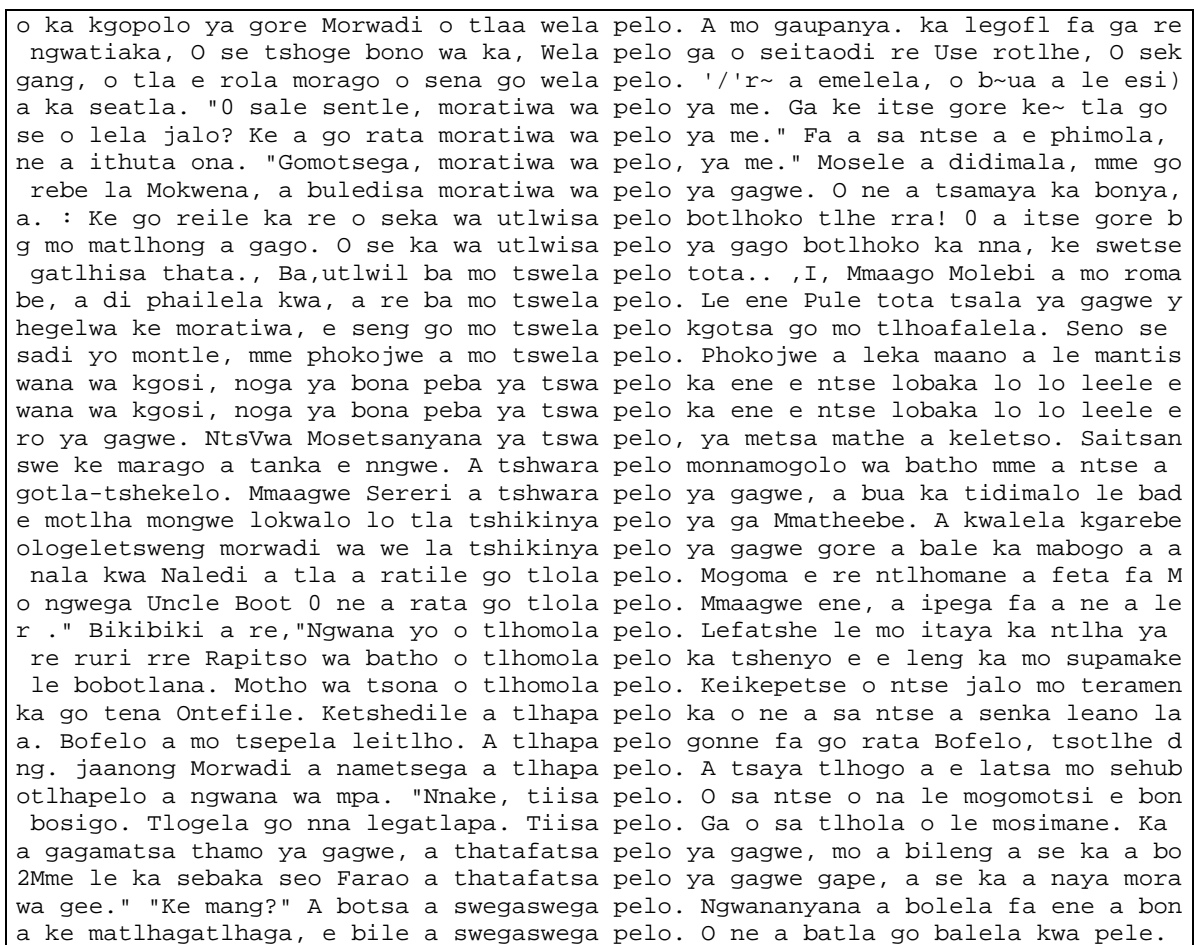

In the above concordance lines, pelo together with its collocates, is rarely used to convey the meaning of the physical heart, "a hollow muscular organ that pumps the blood through the circulatory system by rhythmic contraction and 
dilation" (Pearsall 1998: 847). In the first lines, wela pelo, which literally translates as "have your heart fall down", means "be at peace or be settled". In the next lines, moratiwa wa pelo (the loved one of the heart) is equivalent to "sweetheart" or "beloved". Further on, tshwara pelo (handle or hold the heart) means "be in control of your emotions".

It is by inspecting collocates that we can uncover different MWEs such as proverbs, compounds, idioms, sayings, phrasal verbs, etc. Such structures can then be entered into dictionaries as sub-entries. Through the use of computer programs or concordance software, it is relatively easy to obtain a list of all the co-occurrences of a particular word in context and see all the meanings associated with the word (Biber et al. 1998: 27). The concordance lines above reveal the different subtle meanings associated with the word pelo. From such a study of concordance lines, a possible 84 sub-entries of the headword pelo have been extracted:

ama pelo
balabala ka pelo
baya pelo
beta pelo
betwa ke pelo
bofa pelo
bolawa ke pelo
bolwetse jwa pelo
bona pelo
bongwefela jwa pelo
bonosi jwa pelo
boteng jwa pelo
bua ka pelo
bula pelo
busa pelo
fela pelo
feretlha pelo
fetola pelo
gapa pelo
garoga pelo
kgaoga pelo
go sena letsapa le fisang pelo
gonolwa ke pelo
isa pelo mafisa
itaya pelo
itse pelo
kgwaralatsa pelo
lala ka pelo e rotha madi

$\begin{array}{ll}\text { mabetwa-e-pelo } & \text { pelo yotlhe } \\ \text { masetla pelo } & \text { pelo-e-thata } \\ \text { matlhomola pelo } & \text { pelo-kgale } \\ \text { matlhotlha-pelo } & \text { pelo-telele } \\ \text { nametsa pelo } & \text { pelo-tlhomogi } \\ \text { ngomola pelo } & \text { pelo-tshetlha } \\ \text { ngona pelo } & \text { phatlola pelo } \\ \text { nna pelo } & \text { ritibatsa pelo } \\ \text { nona pelo ka mathe } & \text { sephiri sa pelo } \\ \text { ntsha pelo } & \text { sera pelo } \\ \text { ntsha pelo pelaelo } & \text { sethunya sa pelo } \\ \text { pateletsa pelo } & \text { sisa pelo } \\ \text { pelo e boela mannong } & \text { sulafatsa pelo } \\ \text { pelo e e botlhoko } & \text { swa pelo } \\ \text { pelo e e letlapa } & \text { swegaswega pelo } \\ \text { pelo e ja serati } & \text { thiba maroba a pelo } \\ \text { pelo e khibidu } & \text { thuba pelo } \\ \text { pelo e rotha madi } & \text { tlala pelo } \\ \text { pelo e rutha } & \text { tlalelana pelo } \\ \text { pelo e setlhogo } & \text { tlhomola pelo } \\ \text { pelo e thata } & \text { tlola pelo } \\ \text { pelo khutshwane } & \text { tshwara ka pelo } \\ \text { pelo namagadi } & \text { tshwara pelo } \\ \text { pelo ntsho } & \text { tswa pelo } \\ \text { pelo pedi } & \text { tswela pelo } \\ \text { pelo pholwana e a golegwa } & \text { uba pelo } \\ \text { pelo potsane e a golegwa } & \text { wa pelo } \\ \text { pelo tshweu } & \text { wela pelo } \\ & \end{array}$


In Table 1 below, only 10 of these are explained.

Table 1: Corpus-derived possible sub-entries for the entry pelo

\begin{tabular}{|l|l|l|}
\hline Collocates & Literal translation & Meaning \\
\hline ama pelo & touch the heart & hurt someone \\
\hline balabala ka pelo & $\begin{array}{l}\text { speak too much by the } \\
\text { heart }\end{array}$ & $\begin{array}{l}\text { talk aloud to yourself; be } \\
\text { absent-minded }\end{array}$ \\
\hline baya pelo & put the heart & relax; lay back \\
\hline beta pelo & suffocate the heart & persevere \\
\hline betwa ke pelo & be choked by the heart & be very angry \\
\hline bofa pelo & tie the heart & restrain yourself \\
\hline bolawa ke pelo & be killed by the heart & $\begin{array}{l}\text { desire something but be } \\
\text { unable to acquire it }\end{array}$ \\
\hline bolwetse jwa pelo & the disease of the heart & $\begin{array}{l}\text { heart attack } \\
\text { see somebody's intentions } \\
\text { or thoughts }\end{array}$ \\
\hline bona pelo & see the heart & $\begin{array}{l}\text { be troubled to the extent } \\
\text { that you talk to yourself }\end{array}$ \\
\hline bua ka pelo & speak with the heart &
\end{tabular}

In Setswana, the phenomenon of idiomaticity when considering a word and its collocates is not unique to pelo. Words like molomo (mouth), mpa (stomach), nkô (nose), monwana (finger), kgomo (cow), and many others display similar characteristics. Such idiomatic expressions can enrich dictionary entries as subentries. Tables $2-5$ present the idiomatic expressions for molomo (mouth), mpa (stomach), lonaô (foot) and matlhô (eyes) respectively which have been extracted through studying concordance lines.

Table 2: Corpus-derived possible sub-entries of the entry molomo

\begin{tabular}{|l|l|l|}
\hline Collocates & Literal translation & Meaning \\
\hline bolwetsi jwa tlhako le molomo & disease of hoof and mouth & foot and mouth disease \\
\hline itoma molomo wa tlase & bite the lower mouth & be determined \\
\hline itshwara molomo & hold/touch the mouth & be shocked \\
\hline ntsha ka molomo & release with the mouth & speak \\
\hline pula molomo & $\begin{array}{l}\text { that which opens the } \\
\text { mouth }\end{array}$ & $\begin{array}{l}\text { money paid before some- } \\
\text { one speaks in lobola } \\
\text { negotiations }\end{array}$ \\
\hline pipa-molomo & $\begin{array}{l}\text { that which covers the } \\
\text { mouth }\end{array}$ & a bribe \\
\hline rwala molomo & $\begin{array}{l}\text { carry the mouth on your } \\
\text { head }\end{array}$ & $\begin{array}{l}\text { be angry and tight- } \\
\text { lipped }\end{array}$ \\
\hline roka molomo & sew the mouth & remain quiet \\
\hline tswa molomo & grow a mouth & speak \\
\hline tlhoka molomo & lack a mouth & have nothing to say \\
\hline
\end{tabular}


Table 3: Corpus-derived possible sub-entries for the entry mpa

\begin{tabular}{|l|l|l|}
\hline Collocates & Literal translation & Meaning \\
\hline bana ba mpa & children of a stomach & relatives \\
\hline bipa mpa ka mabele & $\begin{array}{l}\text { cover the stomach with the } \\
\text { breasts }\end{array}$ & $\begin{array}{l}\text { withhold bad information } \\
\text { to protect a relative or } \\
\text { friend }\end{array}$ \\
\hline gare ga mpa ya bosigo & $\begin{array}{l}\text { in the centre of the belly of } \\
\text { the night }\end{array}$ & in the middle of the night \\
\hline gare ga mpa ya lefatshe & $\begin{array}{l}\text { in the centre of the } \\
\text { stomach of the world }\end{array}$ & in the middle of nowhere \\
\hline gare ga mpa ya naga & $\begin{array}{l}\text { in the centre of the belly of } \\
\text { the wilderness }\end{array}$ & in the middle of nowhere \\
\hline mpa ya sebete & the belly of the liver & flat on the stomach \\
\hline mpa e tuka molelo & a belly burning fire & filled stomach \\
\hline go ja ka mpa tsoopedi & eat with two stomachs & eat until the stomach is \\
full
\end{tabular}

Table 4: Corpus-derived possible sub-entries of the entry lonaô/dinâ

\begin{tabular}{|c|c|c|}
\hline Collocates & Literal translation & Meaning \\
\hline apaya ka lonaô & cook with a foot & $\begin{array}{l}\text { avoid cooking and eat at } \\
\text { other people's homes } \\
\text { instead }\end{array}$ \\
\hline goga dinaô & drag the feet & move slowly \\
\hline fodisa dinaô & cool the feet & have a rest \\
\hline motsamaya ka dinaô & $\begin{array}{l}\text { one who walks with the } \\
\text { feet }\end{array}$ & a pedestrian \\
\hline ngotla dinaô & reduce the feet & walk slower \\
\hline tlhatlosa dinâ̂ & raise the feet & walk faster \\
\hline baya lonaô & put a foot & be in a place \\
\hline tsholetsa dinaô & lift the feet & walk faster \\
\hline kgwele ya dinaô & ball of the feet & football \\
\hline tsosa dinâ̂ & wake up the feet & walk faster; hurry up \\
\hline tiisa dinâ̂ & strengthen the feet & walk faster \\
\hline
\end{tabular}

Table 5: Corpus-derived possible sub-entries of the entry mathô

\begin{tabular}{|l|l|l|}
\hline Collocates & Literal translation & Meaning \\
\hline bula matlhô & open the eyes & $\begin{array}{l}\text { educate; make aware; } \\
\text { open the eyes }\end{array}$ \\
\hline diga matlhô & drop the eyes & look down \\
\hline digalase tsa matlhô & glasses of the eyes & spectacles; sunglasses \\
\hline
\end{tabular}




\begin{tabular}{|l|l|l|}
\hline latlhela matlhô & throw the eyes & look briefly \\
\hline matlho a phage a lebane & $\begin{array}{l}\text { the eyes of a wild cat face } \\
\text { to face }\end{array}$ & face to face \\
\hline kala matlhô & measure the eyes & confuse \\
\hline tlodisa matlhô & make the eyes jump & $\begin{array}{l}\text { overlook someone or } \\
\text { something }\end{array}$ \\
\hline kgarakgaratsha matlhô & $\begin{array}{l}\text { make the eyes move from } \\
\text { one place to another }\end{array}$ & $\begin{array}{l}\text { look from one place to } \\
\text { another }\end{array}$ \\
\hline tlhatlosa matlhô & raise the eyes & look up \\
\hline tlhaetsa matlhô & shorten the eyes from & despise someone \\
\hline
\end{tabular}

\section{Treatment of multi-word units in Setswana dictionaries}

When idiomatic collocates are treated as sub-entries in dictionaries, it is important that the type of dictionary should be kept in mind. Normally general dictionaries, which have a more inclusive nature can accommodate more subentries than standard or school dictionaries, which, because of their smaller nature, have to exclude many sub-entries. In the case of very economical, restrictive and selective dictionaries, all sub-entries will have to be omitted. When, in the following discussion, we therefore indicate how the sub-entries in some Setswana dictionaries may be increased, it does not necessarily mean that all these sub-entries should be included. It merely shows what are available. When a choice has to be made, which sub-entries have to be included in accordance with a specific type of dictionary, corpus evidence will be helpful to indicate which idiomatic collocates are the most commonly and generally used.

Setswana dictionaries have attempted to include sub-entries based on the idiomaticity of collocates. However, some of these have been few because of a lack of sufficient corpus evidence. Above we have shown that 84 sub-entries for pelo could be extracted from a corpus. When the entry pelo in Matumo (1993: 306-3007) is referred to, we can see that he lists only 20 sub-entries. Presented below are examples of how the entry molomo has been treated in Setswana dictionaries to illustrate the nature and extent of this.

Brown (1925: 210) identifies only two sub-entries kgwedi ya molomo and go cwa molomo:

Molomo, n., pl. melomo, A mouth (outside); a beak of a bird; a foreskin. Kgwedi ea molomo, the first month of the Sechuana year; the month of eating first-fruits. Go cwa molomo, to open the mouth, in speaking.

Kgasa (1976: 71) does not list any sub-entry for molomo. It may be that Kgasa's dictionary, which was aimed at primary schools was simplified for this reason; he might have seen no need to complicate entries with sub-entries:

molomo(me) kgôrô e dijô di yang mo 'ganong ka yônê. 
Kgasa and Tsonope (1998: 171) list only a single sub-entry: molomo o tlola noka e tletse (a claim is easy to make):

mo•lomo TTT $\ln . / 3$. me-. phatlha e e tswalwang ke dipounama tse pedi e go tsenngwang dijô ka yônê go ya ko mpeng le go bua. molomo o tlola noka e tletse = motho o kgôna go bua dilô tse di ntsi tse a ka di dirang mme ntswa a se ka ke a kgôna

While Snyman et al. (1990) do not enter molomo in their dictionary at all, Matumo (1993: 260) lists only two sub-entries, go tswa molomo and sejô sennye ga se fete molomo:

molomo, N. CL, 3 mo-. SING. OF melomo, a mouth; lip; a beak of a bird; an opening, as a tube, piping or tunnel; a foreskin. ID. EXPR., go tswa molomo, to open the mouth in speaking. PROV., sejô sennye ga se fete molomo.

All the above dictionary treatments of the entry molomo are deficient and will benefit greatly from the use of corpus evidence. For instance, the definition from Matumo (1993) may be revised in the following way, - being used to mark a sub-entry. This shows how the study of collocations can enrich dictionary entries.

molomo, $n$. 1. mouth 2. a lip 3. a beak 4. an object opening, as that of a bottle bolwetsi jwa tlhako le molomo: foot and mouth disease $\mathbf{c}$ itoma molomo wa tlase: be determined D itshwara molomo: be shocked a ntsha ka molomo: speak; express an opinion; express a view a pula molomo: money paid before someone speaks during lobola negotiations a pipa molomo: a bribe r rwala molomo: be angry and tight-lipped a roka molomo: remain quiet $\mathbf{0}$ tswa molomo: speak; say something; contribute; express an opinion a thoka molomo: have nothing to say; be dumbstruck; be rendered speechless molomo o tlola noka e tletse: it is easy for someone to claim that they can achieve what they cannot do

We conclude this section by illustrating how dictionary entries for mpa, lonâ and matlhô could be enriched by means of information in Tables 2-5 derived from a corpus. The proposed entries in each case are compared with entries from Matumo (1993).

Matumo (1993: 276):

mpa N. CL, 9ฤ-, SING. OF dimpa, a belly; a stomach. ID. EXPR. mpa ya lentswê, the middle of a hill; mpa ya lonao, the sole of a foot. PROV., seboba re bata sa mokwatla sa mpa re a mpampetsa.

Matumo's entry of mpa with only three sub-entries may be improved in the following manner with the addition of nine sub-entries:

mpa $n$. a belly; a stomach $\mathbf{0}$ bana ba mpa: relatives bipa mpa ka mabele: withhold bad information to protect a relative or friend gare ga mpa ya bosigo: 
in the middle of the night $\mathbf{q}$ gare ga mpa ya lefatshe/naga: in the middle of nowhere a mpa ya sebete: flat on the stomach a mpa e tuka molelo: with a full stomach d go ja ka mpa tsoopedi: eat until the stomach is full $\mathbf{0}$ ntsha (senya) mpa: commit abortion $\mathbf{0}$ imelwa ke mpa: have a full stomach

Matumo (1993: 212):

lonaô N. CL. 11 lo-, SING OF dinâ, a foot. ID EXPR, go baba lonâ̂.

Matumo's entry of lonaô with a single sub-entry may be improved with the addition of eleven sub-entries as follows:

lonaô $n$. a foot వ apaya ka lonaô: avoid cooking and eat at other people's homes instead goga dinaô: move slowly $\square$ fodisa dinaô: take a rest $\mathbf{\square}$ motsamaya ka dinaô: a pedestrian a ngotla dinaô: walk slower a tlhatlosa dinaô: walk faster $\square$ baya lonaô: set foot in a place $\mathbf{\square}$ tsholetsa dinaô: walk faster $\mathbf{\square}$ kgwele ya dinaô: football $\square$ tsosa dinaô: walk faster $\square$ tiisa dinaô: walk faster

Matumo (1993: 232):

matlhô N. CL. 6 ma-, PL OF CL. leitlhô; maitlhô is still used in a few areas, eyes.

Matumo's entry of matlhô which lacks any sub-entry, may be improved by the addition of nine sub-entries:

matlhô $n$. eyes. ם bula matlhô: educate, make aware, enlighten d diga matlhô: look down a digalase tsa matlhô: spectacles, sunglasses a latlhêla matlhô: look briefly d matlhô a phagê a lebane: face to face d kala matlhô: confuse tlodisa matlhô: overlook someone or something घ kgarakgaratsha matlhô: look from one place to another $\mathbf{d}$ thatlosa matlhô: look up

The updating does not only apply to the bilingual dictionaries. Monolingual Setswana dictionaries could be enhanced in a similar manner, as the following example of tsaya (take) from Kgasa and Tsonope (1998: 303):

tsaya GT'tseile tpt. -ile. 1. tlosa sengwe fa se ntseng se le teng ka go se tsenya mo diatleng tsa gago 2. inêêla ka molaô ga monna go tshela le mosadi; nyala go tsaya seditse = go dumêlwa ke ba bangwe mo go se o se buileng

Kgasa and Tsonope's treatment of tsaya with a single sub-entry may be revised in the following comprehensive manner with the aid of concordance lines to add 28 sub-entries:

tsaya $l d$. 1. amogela mo diatleng 2 . sutisa sengwe fa se neng se le teng 3 . tsamaya ka tselana; ya ntlheng nngwe 4. nyala 5. nna le sengwe; tshola $\mathbf{x}$ tsaya botshelo: bolaya a tsaya dinopolo: utswa diphiri a tsaya ditaelo: sala morago melawana $\mathbf{a}$ tsaya ka motlhala: sala morago a tsaya dipilisi: metsa dipilisi $\mathbf{0}$ tsaya karolo: nna le seabe a tsaya ka letsogo la molema: sotla; nyatsa; kgetholola a tsaya kgakololo: amogela kgakololo tsaya kgato: dira sengwe tsaya lobaka: go diragala mo nakong e telele a tsaya mongwe/sengwe 
motlhofo: nyatsa d tsaya puso: simolola go etelela mmuso d tsaya phekelo e sele: go senyegela pele $\mathbf{a}$ tsaya tshwetso: dira mogopolo $\mathbf{D}$ tsaya nako: iketle $\mathbf{D}$ tsaya motlhala: kopa sengwe se se siameng a tsaya mosadi: nyala d tsaya mogote: thola selekanyo sa mogote mo mongweng a tsaya matsapa: dira sengwe mo nakong e telele $\mathbf{0}$ tsaya tsia: tlotla; thokomela d tsaya malatsi: ikhutsa; nna o ye tirong - tsaya malebela: kopisa sengwe se se ntle d tsaya maikarabelo: nna wena o tshwereng sengwe d tsaya loeto: eta d tsaya maemo: simolola maemo o tsaya setshwantsho: dirisa khamera go tshwantsha $\mathbf{c}$ tsaya sekgele: fenya dsaya sebaka: sengwe sa nako e telele

\section{Conclusion}

In this article, we have attempted to illustrate what could be achieved by a simple study of concordance lines to extract MWEs for the significant improvement of dictionary entries. Considering only single words as candidates for dictionary entry impoverishes a dictionary and betrays a rudimentary understanding of what constitutes a word in language. If Jackendoff's estimate that the number of MWEs in a speaker's lexicon is of the same order of magnitude as the number of single words is accurate, then MWEs in African languages deserve intensive study, which they have hitherto not received. To generate concordance lines is inexpensive, and free concordance programs are available online to aid researchers explore the complexity of texts. Dictionaries of African languages would therefore benefit greatly from populating sub-entries with MWEs harvested from concordance lines.

\section{References}

Aitchison, J. 1992. Teach Yourself Linguistics. London: Hodder \& Stoughton.

Bannard, C. 2007. A Measure of Syntactic Flexibility for Automatically Identifying Multi-word Expressions in Corpora. Proceedings of the ACL Workshop on a Broader Perspective on Multi-word Expressions, Prague, Czech Republic, June 2007: 1-8.

Biber, D., S. Conrad and R. Reppen. 1998. Corpus Linguistics: Investigating Language Structure and Usage. Cambridge: Cambridge University Press.

Brown, T.J. 1925. English Dictionary. Johannesburg: Pula Press.

Brunner, A. and K. Steyner. 2008. Corpus-Driven Study of Multi-Word Expressions Based on Collocations from a Very Large Corpus. Paper presented at the Fourth Inter-Varietal Applied Corpus Studies (IVACS) Conference, University of Limerick, Ireland, 13-14 June 2008.

Dash, N.S. and B.B. Chaudhuri. 2000. The Process of Designing a Multidisciplinary Monolingual Sample Corpus. International Journal of Corpus Linguistics 5(2): 179-197.

Fazly, A. and S. Stevenson. 2007. Distinguishing Subtypes of Multiword Expressions Using Linguistically-motivated Statistical Measures. Proceedings of the ACL Workshop on a Broader Perspective on Multi-word Expressions, Prague, Czech Republic, June 2007: 9-16.

Finch, G. 2000. Linguistic Terms and Concepts. Basingstoke: Macmillan Press.

Jackendoff, R. 1997. The Architecture of the Language Faculty. Cambridge, MA: MIT Press. 
Kgasa, M.L.A. 1976. Thanodi ya Setswana ya Dikole. Cape Town: Longman.

Kgasa, M.L.A. and J. Tsonope. 1998. Thanodi ya Setswana. Gaborone: Longman.

Leech, G., M. Deuchar and R. Hoogenraad. 1982. English Grammar for Today: A New Introduction. Basingstoke: Macmillan Press.

Matumo, Z.I. 1993. Setswana-English-Setswana Dictionary. Gaborone: Macmillan.

McArthur, T. 1998. Living Words: Language, Lexicography and the Knowledge Revolution. Exeter: University of Exeter.

Moon, R. 1998. Fixed Expressions and Idioms in English: A Corpus-based Approach. Oxford: Oxford University Press.

Oflazer, K. and Ö. Çetinoğlu. 2004. Integrating Morphology with Multi-word Expression Processing in Turkish. Second ACL Workshop on Multi-word Expressions: Integrating Processing, Barcelona, Spain, July 2004: 64-71.

Otlogetswe, T.J. 2007. Corpus Design for Setswana Lexicography. Unpublished Ph.D. Thesis. Pretoria: University of Pretoria.

Pearsall, J. 1998. The New Oxford Dictionary of English. Oxford: Oxford University Press.

Renouf, A. 1987. Corpus Development. Sinclair, J.M. (Ed.). 1987. Looking Up. An Account of the COBUILD Project in Lexical Computing and the Development of the Collins COBUILD English Language Dictionary. London/Glasgow: COBUILD.

Sag, I.A., T. Baldwin, F. Bond, A. Copestake and D. Flickinger. 2002. Multiword Expressions: A Pain in the Neck for NLP. Proceedings of the Third International Conference on Intelligent Text Processing and Computational Linguistics (CICLing-2002), Mexico City, Mexico, March 2002: 1-15.

Schone, P. and D. Jurafsky. 2001. Is Knowledge-free Induction of Multi-word Unit Dictionary Headwords a Solved Problem? Proceedings of the 2001 Conference on Empirical Methods in Natural Language Processing, Pittsburgh, PA: 100-108.

Scott, M. 2004-2006. Oxford WordSmith Tools Version 4. Oxford: Oxford University Press.

Sharoff, S. 2004. What is at Stake: A Case Study of Russian Expressions Starting with a Preposition. Second ACL Workshop on Multi-word Expressions: Integrating Processing, Barcelona, Spain, July 2004: 17-23.

Snyman, J.W., J.S. Shole and J.C. le Roux. 1990. Dikisinare ya Setswana-English-Afrikaans Dictionary/Woordeboek. Pretoria: Via Afrika.

Villavicencio, A., A. Copestake, B. Waldron and F. Lambeau. 2004. Lexical Encoding of MWEs. Second ACL Workshop on Multi-word Expressions: Integrating Processing, Barcelona, Spain, July 2004: 80-87. 